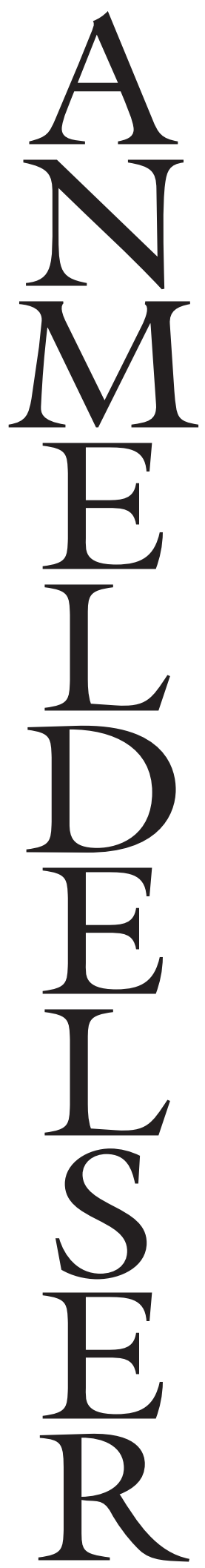

"DET ER DA IKKE RACISTISK!"

OG ANDRE POSITIONER FRA NORDENS RACIALISERINGSDISKURSER

Peter Hervik (red.): Racialization, Racism, and Anti-Racism in the Nordic Countries. Palgrave Macmillan, 2018, 302 sider.

Pris: $103,99 €$

Tdagspressen og på de sociale medier ser vi debatten om racisme og diskrimination tage form igen og igen. Ofte optegnes de samme positioner: Der er dem, der udpeger racistiske hændelser og handlinger, og dem, der fluks angriber disse udpegninger som useriøse og udtryk for 'sarte' menneskers uretfærdige behov. En debat med fast optrukne poler begynder herfra at udspille sig, og det er denne debat, der foretages en begyndende kortlægning af $\mathrm{i}$ antologien Racialization, Racism, and Anti-Racism in the Nordic Countries.

I bogen samles 12 tekster, der især fokuserer på de reaktioner, man i Norden ser i pressen og på de sociale medier, når det kommer til diskussioner omkring racialisering, racisme og anti-racisme. Der er enkelte andre tilgange til feltstudier inkluderet, bl.a. Caroline S. Boe og Karina Horstis kapitel om Norges nordlige grænse ved byen Kirkenes, hvor dele af lokalbefolkningen pludselig begyndte at involvere sig i aktivisme, da flygtninge med behov for varmt tøj krydsede grænsen, og de offentlige instanser ikke trådte til med hjælp. Ud over dette lysglimt omhandler de fleste bidrag dog eksempler på den modsatte tendens.

Antologien skal have ros for ikke at falde i fælden med at trække på de samme større, kendte sager inden for feltet (bl.a. Muhammedtegningerne og massakren på Utøya). I stedet påpeges en række forskelligartede udgangspunkter for indvandrings- og racialiseringsdebatten fra hele Norden. Lige så forskellige eksemplerne fremstår, lige så mange fællesnævnere ser der dog også ud til at være i de diskursive formationer og debatmønstre, der analyseres. Det er således de samme spørgsmål, der er i centrum af debatterne 
igen og igen: Hvornår er noget racistisk? $\mathrm{Og}$ hvem har ret til at definere dette? Det ses bl.a. i Sayaka Osanami Törngrens fremlægning af svenskernes 'farveblinde' tilgang til interraciale xgteskaber, der afslører, at accepten af "andre kulturer" ikke er nået så langt, som man skulle tro. Alligevel mener ingen af de interviewede, at deres bekymringer forbundet med især mellemøstlige æatefæller til majoritetssvenskere har noget med racisme eller diskriminationsstrukturer at gøre.

Tendensen til at debattere definitionen af racisme ses også i eksemplet analyseret af Kjetil Rødje og Tess Sophie Skadegård Thorsen, der omhandler den danske debat om, hvorvidt Djurs Sommerlands "Afrikaland" er racistisk eller ej. Da aktivist Jin Vilsgaard kommenterede sommerlandets coon-karikatur-lignende figurer (med sort hud, røde læber og knogler i håret) og en forlystelse, der gav en tur i "kannibalgryderne", startede det en kaskade af debatter, der centrerede sig om det samme spørgsmål: Er den slags gengivelser problematiske, eller er problemet i virkeligheden de "krænkelsesparate" mennesker, der påpeger problemet? Rødje og Skadegård Thorsen beskriver igennem analyser af nyhedsartikler, blogindlæg, radioprogrammer og debatsider, hvordan positionerne i den danske diskurs tog sig ud: Hvem ser sig berettiget til at bedømme, hvornår noget er racistisk eller ej? Og hvad er konsekvensen af disse debatter for hvem? Samme opskrift, både mht. tilgang og debattens to poler, finder vi i mange af de øvrige bidrag.

I Norden kxmpes der tilsyneladende hårdt for magten til at definere, hvad racegjorte skal finde sig i, både mht. repræsentation og behandling i hverdagen. Der er kun meget få forsøg på at lytte og forstå i de udvalgte cases. Selv inden for det humanistiske forskningsfelt kæmpes der, hvad Mathias Danbolt og Lene Myong tager fat i. De ser på, hvordan enkelte forskeres udgivelser, i dette tilfælde Henning Bech og Mehmet Ümit Necefs bog Er danskerne racister? Indvandrerforskningens problemer, kan samles op af pressen og anvendes som et hovedargument $\mathrm{i}$ den evige debat:
Udøver majoritetsbefolkningen en problematisk og racistisk adfærd, eller er problemet i virkeligheden dem, der påpeger racismen? Antologien gør det med andre ord tydeligt, at definitionskampen omkring "racisme eller ej" kører derudaf i mange forskellige samfundslag og situationer: I xgtesengen, i sommerlandet, i det akademiske miljø. Debatterne, der analyseres, finder deres form og ordlyd igennem pressens fremstillinger og den hårde tone på de sociale medier, hvor positionerne krystalliseres på en måde, der gør det let at optegne og afdække polarisering og normaliserede forståelser i bogens mange eksempler. Selvom bogen arbejder med casestudier, der belyser enkelte tilfælde, tegner der sig altså flere mønstre ved gennemlæsning også mht. kapitlernes tilgang, valg af materiale og konklusioner. De enkelte bidrag, trods forskellige forfattere bag og mange forskellige cases, bliver derfor lidt ensformige, men er let læste. Ikke fordi der ikke er tankestof i teksterne - det er der bestemt - men fordi bogen er ganske velskrevet. Teksterne kan da også let læses og anvendes hver for sig, men kæmper man sig igennem alle kapitler i samme hug, som jeg, begynder der at tegne sig et interessant billede - også selvom stregerne ikke er fuldt forbundne endnu. Der er således lagt et grundlag for flere spændende udgivelser eller forskningsprojekter med samme sigte, hvor de mange eksempler spindes sammen til en række tendenser eller en form for overblik over positioner og diskursformationer omkring racialisering, racisme og anti-racisme i Norden. Det lader dog ikke til, at bogens xrinde er at skabe et sådant overblik, så manglen skal hverken redaktør eller bidragsydere klandres for. En egentlig teoriudvidelse eller en påpegning af tendenser er blot ønsketanker fra en interesseret læser.

Et andet interessant billede, der tegner sig i gennemlæsningen af de 12 bidrag, omhandler hvor Nordens racialiseringsforskning er på vej hen. Bidragsyderne er hovedsageligt 'yngre forskere', dvs. har ikke så høj en 'ph.d.-alder', som redaktøren Peter Hervik pointerer i sin introduktion: "Most of them have finali- 
zed their dissertations on racism, racialization, and anti-racism within the last decade" (s. 5 ). Det er i den forbindelse bl.a. interessant at se, at selvom der ofte diskuteres "migranter", "indvandrere" og "muslimer" i de analyserede debatter, så er det ikke islam- eller migrationsforskningen, der fylder mest i bidragenes kildelister. I stedet ses en stærk indflydelse fra critical race og whiteness studies, fx i form af Eduardo Bonilla-Silva, Ruth Frankenberg og Sara Ahmed, der indirekte kæder de mange kapitler sammen til et samlet felt. Alene af den grund er bogen bestemt en gennemlæsning værd, for forhåbentlig er det begyndelsen på et kommende, samlet felt i Norden, vi her ser tage form.

Sabrina Vitting-Seerup
Ph.d.-stipendiat
Moderne Kultur
Københavns Universitet

\section{LESBIAN DESIRE IN FEMINISM: BETWEEN FRIENDSHIP AND HOMOSEXUALITY}

\author{
Eva Borgström and Hanna Markusson \\ Winkvist (ed.): Den kvinnliga tvasambetens \\ frirum. Kvinnopar i kvinnorörelsen 1890- \\ 1960. Appell Förlag, 2018, 368 pages. \\ Price: 259 SEK.
}

$\mathrm{I}_{\mathrm{r}}^{\mathrm{n}}$ all feminist movements in Western Europe female couples played vital roles, and lesbians, although often by necessity closeted, had key positions. However, the roles of romantic friendships, female cohabitations, not to mention lesbian desires, have from the beginning been problematic and heavily tabooed. There are many good reasons for that: In countries like Finland and Sweden female homosexuality was literally forbidden (although very few women were tried), whereas in countries like the UK, Germany and Denmark laws condemning homosexuali- ty only applied to men. Women were considered asexual beings making female homosexuality impossible. So either condemned as a crime or trivialised as a phantasy, lesbian desire was written out of decent conversation and political struggle.

Furthermore, many antifeminist opponents, like misogynist playwright August Strindberg demonised feminists and portrayed them as unnatural, hermaphroditic, lesbian man haters. So although the early feminist movements were to some degree safe havens for the exploration of lesbian desire and female romanticism and friendships, a large amount of discretion was required. Strangely enough, this discretion has survived in current feminist historiography that even today tends to avoid questions about the significance, extent and meanings of female couples in the midst of early feminist movements.

This alone is ample reason to welcome Borgström's and Winkvist's pioneering endeavor: Den kvinnliga tvasambetens frirum (The free spaces of female partnerships). This anthology contains a daring and stimulating investigation into central female couples in Swedish feminism in the first half of last century, an unafraid attempt to ask and tell about sex, desire and romance. Ten essays, all well written, engaged and engaging, look into female relationships and confront the problems of finding, documenting and analysing traces of desires that are mostly hidden, if not totally absent.

\section{HOW TO READ BETWEEN MISSING LINES}

The project explicitly addresses the challenges of how to make silences, lapses, gaps and subtle hints speak. These problems are also, alas, in quite a few cases - perhaps involuntarily demonstrated. The difficulties in making blank pages speak are obvious in some of the weaker essays that end up telling us little. Winkvist's essay on Beth Hennings and Gina Leffler, two prominent feminists engaged in politics and education that lived together 
most of their adult lives is a prime example. "Love between the lines" is the subtitle but the problem is that there are no lines to look between. The two wrote each other only a few letters and destroyed most of their personal papers. Thus, the result is an unambitious rendition of biographical facts with a few conjectures.

The same criticism can be launched against Carina Burman's essay on Klara Johanson and Ellen Kleman and Irene Anderson's essay on Eva Andén and Lisa Ekedahl; the dull title unfortunately seems appropriate: “- ett gemensamt liv i arbete, vardag og fest” (“- a common life in work, every day and party"). These are informative, polite, pleasant, positivist herstories about seemingly harmonious couples but they barely scrape the surface leaving us guessing about the significance of lesbian desire and female cohabitation.

Ulla Mans in the excellent, short final essay delivers vital clues, if not direct solutions, to this problem of reading queerly and against the heteronormative grain. Inspired by Eve Kosofsky Sedgwick's concept of reparative readings she delivers two subtle examples of how to detect queer openings in silences and omissions. In the essay, Finnish feminist Alexandra Gripenberg's massive, three-volume monograph on feminist reform from 1903 is deconstructed by focusing on what she does not do and what must surely have been a provocation in her time. The "New Woman" is not placed in the family as mother and caretaker and seen not only as a gendered being. The other example is journalist Ellen Kleman's discreet polemic with Ellen Key who in her critical book Kvinnorörelsen (The Women's Movement) from 1909 saw no role in the welfare state for the unmarried woman. Insisting on this position could be Kleman's way of securing a role for the unnameable and unmentionable lesbian. Mans' contextualising strategy to discover subversive strategies in historical documents is a bit like queer literary contextualisation that for instance demonstrates the provocations in a nineteenth century fictional portrayal of a homo- sexual character that does not die at the end of the plot. Spotting emancipatory potential often demands delicate contextualisation.

\section{FrEe SPACES OR COMBAT ZONES}

The other essays are all dense, ambitious and thoroughly enjoyable reads. The famous Selma Lagerlöf caused enough trouble and left behind enough traces to make her complex love affairs interesting; at least they appear so in Eva Ulvros' presentation that focuses mainly on the long relationship with fellow writer Sophie Elkan. The two women's struggles with defining the role of physicality and desire in their relationship have a lot of common traits with male negotiations on love in romantic friendships a hundred years earlier. Sometimes Lagerlöf almost sounds like an echo of the troubled Romanticist Hans Christian Andersen, who was also tormented in his efforts to make sense of his same-sex desires.

Lagerlöf expert Lisbeth Stenberg focuses on the fascinating ménage-à-trois between Toini Topelius, Maria Cederskiöld and the aforementioned Gripenberg; and Ulla Wikander has an interesting and beautiful autoethnographic take on the romance between leading Finnish feminist Vera Hjelt and her fan, Victoria Heikel, Wikander's grandmother. The fascinating and headstrong Lydia Wahlström, a theologian and writer, plays the main role, not only in the life of long-time companion Anita Nathorst, as Borgström masterfully displays, but also in the life of a poor, unknown, devoted school teacher. The love letters from this unknown lesbian to Wahlström were fortunately discovered in the archives and thrown light upon by Lars Garrdfelt.

The essays all explore the "space" produced by these women friends and/or lovers and I certainly understand the pull to call them "free spaces" ("frirum"), female oases in the desert of modern bourgeois patriarchy. But the term sentimentalises and harmonises spaces that in some cases are anything but 
"free" but fraught with possessiveness, power games, jealousy, and tensions, in short, more battle zones than idylls. "Free zone" is a metaphor we can, perhaps, only project on friendships for which we have few documents. Like other passionate relationships these female spaces are anything but "free". This makes them all the more interesting. Just like the questions raised by this handsomely illustrated, inspiring, and somewhat uneven anthology.

Dag Heede

Ph.D, Associate Professor

Department for the Study of Culture

University of Southern Denmark

\section{HVAD GØR VI I DANMARK I KAMPEN MOD SEXCHIKANE - OG HVAD KAN VI GØRE BEDRE?}

\author{
Anette Borchorst og Lise Rolandsen \\ Agustín: Seksuel chikane på arbejdspladsen- \\ Faglige, politiske og retlige spor.
}

Aalborg Universitetsforlag, 2017, 294 sider. Pris: 298 kr.

$\mathrm{H}$ vordan skal mænd opføre sig over for kvinder på arbejdspladsen? Hvilke rettigheder har mænd og kvinder, når vi omgås hinanden? \#MeToo-debatten har sat gang i mange tanker og initiativer over det sidste års tid - særligt uden for Danmark. Nu er der endelig kommet et fagligt velfunderet og vildt spændende indspark i debatten fra de to danske forskere, professor Anette Borchorst og lektor Lise Rolandsen Agustín. Så hvis du går op i ligestilling - og gerne vil vide mere om aktørerne i den danske kontekst - så er denne bog lige noget for dig! Det er ikke opmuntrende læsning (hvis du er feminist), men bogen giver et virkelig spændende og tiltrængt indblik i, hvordan Danmark ikke er det progressive ligestillingsland, som mange (inklusiv danskerne selv) ofte går og tror. En af bogens pointer er nemlig, at ligestillingsfremskridt i Danmark primært er opnået på grund af europæisk pres.

Borchorst og Agustín beskriver deres intention med bogen således: "Formålet med bogen er at forklare, hvordan håndteringen af seksuel chikane har udviklet sig i Danmark i spændingsfeltet mellem lovgivning, politisk og faglig regulering samt retspraksis med interesse for arenaer og aktører. Det gør vi ved at analysere, hvem og hvad der har drevet sexchikanepolitikken i Danmark. Bogen fokuserer på et politisk, et fagligt og et retligt spor samt på, hvilke barrierer der er for at håndtere seksuel chikane på arbejdspladsen” (s. 12). Bogens analyse bygger på sagsmateriale fra retlige instanser, politiske debatter, materiale fra skriftlige medier og ikke mindst på ekspertinterviews med jurister, psykologer, fagforbund, arbejdsgiverorganisationer og arbejdstilsynet. På den måde kombineres den allerede offentligt tilgængelig viden med eksperternes akkumulerede insider-viden inden for feltet. Grundlaget for bogens forskning er dermed solidt baseret i den danske kontekst og guidet af de eksperter, der arbejder med problematikken i praksis.

\section{HVORDAN BLEV SEXCHIKANE NOGET VI} KUNNE ITALESÆTTE SOM DISKRIMINATION? Bogen lægger ud med en introduktion af historikken omkring begrebet sexchikane (sexual harassment), som blev introduceret af den amerikanske jurist Catharine MacKinnon. Hun førte en sag for en klient, der havde været udsat for netop denne for form chikane. I retssagen gjorde MacKinnon op med en forståelse af, at mænd naturligvis vil udøve sexchikane mod kvinder, hvis disse bevæger sig ind på arbejdsmarkedet. I stedet argumenterede MacKinnon for, at seksuel chikane skulle opfattes som diskrimination, fordi det var udtryk for forskelsbehandling af kvinder. Og hun vandt sagen. Dermed begrebsliggjorde hun en diskriminationspraksis på arbejdsmarkedet og opnåede samtidig at definere chikanen som uretfærdig. 
Med definitionen af begrebet og en retslig afstandtagen fra denne form for handlinger fulgte forskning inden for feltet. Bogen fremhæver professor i Gender \& Women's Studies Louise Fitzgeralds spørgeskema Sexual Experiences Questionnaire (SEQ) som et solidt og håndgribeligt værktøj til at afdække problemet. Helt konkret fremhæver Borchorst og Agustín, at spørgeskemaet styrke er, at der stilles mange konkrete spørgsmål til personers oplevelse på arbejdspladsen. Spørgeskemaet sigter således efter at indfange sexchikane meget bredt forstået og inkluderer derfor alle tre sub-kategorier af sexchikanen (kønschikane, uønsket seksuel opmærksomhed og seksuel tvang): "[1] Kønschikane: En rxkke verbale og ikke-verbale handlinger, der giver udtryk for fornærmende, fjendtlige og nedværdigende holdninger til kvinder. [2] Uønsket seksuel opmærksomhed: Verbale og ikke-verbale handlinger, gentagne, ikke-gensidige anmodninger om dates, påtrængende breve og telefonopkald, berøring, greb, trængen op i et hjørne, grove seksuelle tilnærmelser og angreb. [3] Seksuel tvang: Bestikkelse og trusler, der eksplicit eller underforstået forbinder jobrelaterede fordele med seksuel adfærd" (s. 64).

\section{HVAD KAN VI GØRE FREMOVER} FOR AT FORHINDRE SEXCHIKANE?

Både introduktionen til begrebets historik og de konkrete værktøjer, vi kan bruge til at måle problemets omfang, er ekstremt relevante. Men min absolutte favoritdel af bogen er, når forskerne tager sig tid til at anvende alle deres ekspertkilders viden til at udforme anbefalinger for best practice. Konkret anbefaler Borchorst og Agustín, at organisationer har klare procedurer for, hvor man skal henvende sig, og hvad man som medarbejder skal gøre, hvis man ønsker at anmelde tilfælde af sexchikane. De understreger, at der skal være mulighed for at anmelde tilfælde anonymt $i$ form af whistleblower-ordninger, hvor både ofre og vidner kan henvende sig og rette opmærksomhed mod problematisk adfærd i organisa- tionen. De understreger også, at organisationer bør bruge hvert tilfælde af sexchikane som en læringsmulighed for at afdække både, hvad der gik galt i det konkrete tilfælde, og hvordan man kan rette op på problemet. $\mathrm{Og}$ de efterspørger APV-undersøgelser (arbejdspladsvurderinger), der finder inspiration i Fitzgeralds Sexual Experiences Questionnaires konkrete spørgsmål, således at omfanget af problemet faktisk kan indfanges med APVundersøgelser i organisationen. Det er meget simple og konkrete løsningsforslag, som entydigt signalerer, at hvis vi vil sexchikanen til livs på arbejdspladsen, så må vi gøre op med en opfattelse af, at det er offerets ansvar at ændre organisationens kultur. I stedet placeres ansvaret for kulturændringen primært på organisationens og dermed ledelsens skuldre. Forskerne opsummerer det, så det fremstår enkelt: "Gennemgående er budskabet, at det er vigtigt, at virksomheder har en klar og synlig politik, at ledelsen tydeligt signalerer, at der er nultolerance over for seksuel chikane og mobning, at det er klart, hvor man kan henvende sig, herunder også med garanti for anonymitet, samt at der er en procedure for behandling af sager, hvis de rejses" (s. 163). Bogen tilbyder endda inspirerende eksempler med organisationer, der er gået eksemplarisk til værks og har haft stor succes med at reducere tilfældene af sexchikane og dermed har øget trivslen på arbejdspladsen.

Opsummerende kan man sige, at bogen tilbyder et helt unikt indblik i, hvad danske organisationer og politikere på nuværende tidspunkt gør (og ikke gør) i forhold til at forhindre sexchikane på arbejdspladsen - og hvad vi bør gøre anderledes, hvis alle skal have lige adgang til det danske arbejdsmarked i fremtiden. Derfor er denne bog helt klart det første - og et meget spændende - skridt på vejen til et dansk arbejdsmarked med videnskabeligt velfunderede praksisser omkring interventioner imod sexchikane.

Lea Skewes, postdoc

Tema Genus

Linköping Universitet 


\section{REVIEW ESSAY}

\section{CHALLENGING AND ECHOING THE NUCLEAR FAMILY}

Rikke Andreassen: Mediated Kinship. Gender, Race and Sexuality in Donor Families.

Routledge. 2018, 190 pages. Price: 1.379,95

DKK; available for free online from:

https://www.taylorfrancis.com/books/9781 351233439 .

\section{Tn 2016, I gave birth to a child. Without \\ using the concept myself, I became part of the} growing group of 'solo-mothers' which were increasingly being debated in various forums on the internet and in popular media. Debates that I interestedly followed and participated in, despite the fact that they often ended up in a strange mishmash of normative family endeavors with the nuclear family as the highest ideal. "As if this was our dream", the solo mothers replied when they were repeatedly criticized as being selfish and picky men-haters, "we'd rather have a father to our children, being a solo mother was only plan B." Apparently, feminist perspectives on alternative family forms had not gained entry into the popular debate of solo-mothering nor the solo-mothers' self-understanding.

It should be no secret that I welcome Rikke Andreassen's new book on Mediated Kinship. Gender, Race and Sexuality in Donor Families and its involvement in the diversity of alternative family making. Research into alternative families has long been consolidated as a field of study for gender studies. Gender studies scholars have investigated processes of alternative meaning-making and alternative 'doings' of family and parenthood while comparing these 'deviations' with norms of the nuclear heterosexual family. Rikke Andreassen's new book is well positioned within this tradition but it approaches alternative family making a bit differently. Instead of working from a 'norm - deviation' point of departure, Andreassen focusses on how different forms of donor families negotiate their way of making a family, the ways they differ from each other, and how norms of parenting and kinship take different shapes depending on the actual family these norms work in. Not only does this approach show donor families as a less homogenous group, it also produces new knowledge. One example is 'solo-mothering', which, as a relatively new phenomenon, has not received the same analytical or activist attention as other forms of alternative parenting. In Andreassen's work, we get new knowledge about this specific group, but the negotiations on kinship made by solo-mothers also offer us new perspectives on the dynamics happening within other forms of donor families.

The focus on diversity is definitely a strength of the book. Although queer families are still 'alternative', they are so in an increasingly diverse landscape. Andreassen's interest is particularly focused on how this diversity is played out in the intersection with social media and especially Facebook. Throughout the book, we follow different examples of what happens in this intersection: How social media offers a virtual space for exchanging experience and collective identity formation to the 'outsiders' of the nuclear family. How kinship is negotiated and how norms of 'doing family' are tied with gender, race and sexuality in new - and not so new - ways. It does not mean that we lose sight of the normative in the nuclear family. Throughout the book, we get a variety of insights into how donor families struggle with family ideals: How they mirror, mime and wrestle with these norms, and how alternative parenting keeps the ideal of a nuclear family both intact and frayed at the same time.

\section{Couple-DOM}

In my own network, there are both lesbian couples and solo-mothers. Since we all went through the same procedure of making children, it was obvious to discuss our choices of donor. My lesbian friends were often in favour of using anonymous donor sperm. Besides being a practicality, the donor had no role; they would be a family after all. I felt the same. I ascribed no importance to genetically inberited favorite 
food or color preferences, so why should I use this information? I chose an anonymous donor and gave the information to the fertility clinic. Almost immediately I changed my mind. What if my future child was burdened by my rejection of contact with the donor? Deselection in various forms began to flourish in my thoughts. Would my future child be angry with me about opting out a father? Annoyed about these thoughts, I wondered why I concerned myself with these questions while the lesbian couples apparently did not. Why was it so difficult to ignore it? Why was I in a process of opting out when they were in the process of making a family?

Andreassen's analysis of discussions on Facebook donor fora as well as her interviews with different types of donor families shows how the view of biological kinship varies greatly in these families. While donor families share the use of donor sperm as a prerequisite for having children, lesbian and solo-mother families relate differently to the meaning of kinship and draw different borders for who counts as members of their family: Solo-mothers more often engage in finding donor siblings to their child, whereas lesbian families tend to see other biological offspring as 'objects of threat' to their (already complete) family. This is an interesting finding showing the flexible boundaries of kinship. Furthermore, Andreassen's focus on the variety in alternative ways of doing kinship leads her to engage in a topic which has been absolutely absent in the debate on alternative families: The norm of the two-parent family or what Andreassen calls "couple-dom". Couple-dom is a culture's expectations of every child as having two parents and, as Andreassen illustrates, this norm is so strong that is has become central in the so-called principle of the best interest of the child. The child's best interest principle, which was particularly strengthened by the United Nations' grant of individual rights to children in 1989, works as a guideline in everything from judicial decisions of divorce cases to cultural provisions of good parenting and definitions of what a family is. Andreassen shows how the online discussions between mothers(-to-be) are spurred by a thinking of children as entitled to both parents and how the donor child, therefore, has a right to know its biological origin. How the principle disciplines choices of sperm donors and desires of making a certain family and thus how it works with a strong reference to the nuclear family.

Again, there are variations between different donor families. Since lesbian families succeed in living the norm of couple-dom, they are able to understand their family as 'complete'. This explains why more lesbian couples than solomothers choose an anonymous donor: Although lesbian families clash with a range of heteronormative standards, they are after all two parents. The situation is obviously a bit different for solo-mothers, who seem to struggle with a status of being an 'amputated family'. That solo-mothers tend to choose open donors is a way to offer the child some kind of father and thereby mitigate for their solo-dom. In that, Andreassen argues that lesbian families to a greater extent mimic the nuclear family norm of two parents, while solo-mothers challenge it, saying "that coupledom seems to trump heterosexuality and that single heterosexual parents are more marginalised than lesbian couples today" (p. 66). While I do not believe that couple-dom makes lesbian mothers 'better off' in general, it is an important point for research on parenting ideals and family constructions. While solo-mothering might challenge norms of couple-dom and open up for new family forms, solo-mothers on a personal level have to struggle to be accepted as a family and this contains a lot of emotional issues. Solo-mothers' discussions are thereby more often concerned with problems of the absent father (as there are no other parental role models), the selfish mother (depriving the child a parent), and their fragile family constellation (what if the only parent dies). Solo-mothers' greater willingness to choose open donors and to include donor siblings in their family might thus both create a broader family concept and challenge the nuclear norm, but also mimic a 
narrative of the biological family as a 'real' family and the 'real' family as a family with two parents and more siblings.

These diverse negotiations offer great insights into how kinship differs depending on how it is situated. For example, is the donor a father, a member of the family, a biological relative, or a provider of genetic material? Andreassen's work illustrates that the answer is not so much related to the donor, but rather to the family's distance or closeness to social norms of family making. The same donor can thus both be a 'father' and 'pure DNA'. This shows how the broadening of kinship boundaries and challenging of heterosexual family norms can take place at the same time as the nuclear family remains an ideal for alternative family forms.

\section{SAFE SPACES FOR CHALLENGING FAMILY NORMS}

When I was pregnant, I signed up for antenatal classes for solo-mothers. Except two, we all became pregnant through MAR with donor sperm. Of the two exceptions, one had become pregnant after a one-night flirt and the other was pregnant with her husband, whom she brought along to the class. Our teacher stressed that the couple was in the wrong class. The couple apparently agreed, but as they kept saying, they would just stay in this class, it was okay with them, they did not mind. The rest of us just stared at them and at least I wondered if they did not understand that we would mind? That finally we were offered a space where everyone was in the same boat, where information could actually be addressed to us and did not have to be twisted through norms of becoming mom and dad. Fortunately, the teacher was stubborn and the couple left the group.

We might think that this is a rather depressing picture of the family anno 2019, which, despite great diversity, still drags the nuclear family around as its highest ideal. However, there are also new openings and not least new communities. While social media offers a platform for discussing - and reproducing family norms and ideals, it also creates a space for new family relations to emerge. Andreassen shows how closed Facebook groups allow the making of extended families and new relatives by offering an easy form of contact. Parents just need to upload a picture of their child to link and maintain new family ties. As such, these Facebook groups work as safe spaces, making alternative families the norm instead of the deviation. They are spaces for common understanding, spaces that facilitate communication and a feeling of belonging to a community. Affective spaces, which move the boundaries of familial intimacy at home to include people in other parts of the country and even on other sides of the world. Although alternative families might still struggle with norms, they increasingly struggle together with someone in the same situation.

Andreassen's book both illustrates the inertia and renewal of family norms as well as the ambivalence between them. It shows how real people negotiate cultural narratives about the good family and the right parenthood. How no one reproduces the standards fully, but that some does it more than others do. The book is solidly rooted in feminist theory and provides an impressive bank of knowledge to studies of donor families, kinship, queer parenting, race, sexuality, and media research. As such, Andreassen's book touches upon more aspects of mediated kinship (hence the book title) in donor families than what I have mentioned here. For me, the book both put into words some of the dilemmas I experienced myself and initiated new reflections for my research into mothering and family dynamics. I therefore find it a very relevant book for both Danish and international gender studies researchers, and also for those families who want to recognize or discover - themselves in it.

\section{Michala Hvidt Breengaard PhD, Postdoc \\ Department of Sociology \\ University of Copenhagen}

